\title{
PENGARUH MASYARAKAT SEKITAR NABI S.A.W. TERHADAP KEBERADAAN HADIS
}

\author{
Oleh: \\ Muhammad Zulkarnain Mubhar, S.Th.I., M.Th.I. ${ }^{1}$
}

\begin{abstract}
Abstrak
Hadis Nabi merupakan sumber ajaran Islam kedua setelah Al-Qur'an, yang setiap muslim wajib mengikuti dan mengamalkan ajaran-ajaran yang terdapat di dalamnya. Karena sifatnya yang demikian, maka mempelajari hadis juga merupakan keharusan bagi setiap muslim. Karena, untuk beramal dengan ajaranajaran yang terdapat dalam hadis-hadis Nabi, seseorang minimal harus mengetahui hal-hal yang diajarkan di dalamnya. Di samping memahami dan mengkaji hadis, mempelajari ilmu hadis juga menjadi keniscayaan, karena ilmu ini membahas hal ihwal yang terkait dengan Nabi khususnya dari segi dapat tidaknya dijadikan hujjah atau dalil agama Islam. Hadis ( Sunnah) yang lahir tidak dapat terlepas dari kondisi dan situasi masyarakat dimana hadis itu terbentuk, serta tidak lepas dari peran sahabat pada masa itu. Masyarakat dan sahabat adalah merupakan subjek sekaligus objek dari terbentuknya hadis. Hadis hadir mengiringi dan menjelaskan ayat-ayat Al-Qur'an, sekaligus sebagai jawaban-jawaban kejadian-kejadian atau kasus yang sedang terjadi baik masalah ibadah maupun muamalah. Mengingat pentingnya kedua faktor pembentuk lahirnya hadis, yaitu kondisi masyarakat dan peran sahabat, maka untuk mempelajari hadis pada saat ini tidak bisa mempelajari hadis berdasarkan teksnya belaka (tekstual), tetapi perlu juga mempelajari konteks saat hadis itu lahir. Berdasarkan uraian pembahasan di atas, jelaslah bahwa mempelajari hadis perlu mengkaji historis, sosiologis dan antropologis (kontekstual) masyarakat pada saat dimana hadis itu lahir.
\end{abstract}

\section{PENDAHULUAN}

\section{A. Latar Belakang}

Hadis Nabi merupakan sumber ajaran Islam kedua setelah Al-Qur'an, yang setiap muslim wajib mengikuti dan mengamalkan ajaran-ajaran yang terdapat di dalamnya. Karena sifatnya yang demikian, maka mempelajari hadis juga merupakan keharusan bagi setiap muslim. Karena, untuk beramal dengan ajaran-ajaran yang terdapat dalam hadis-hadis Nabi, seseorang minimal harus mengetahui hal-hal yang diajarkan di dalamnya. Di samping memahami dan mengkaji hadis, mempelajari ilmu hadis juga menjadi keniscayaan, karena ilmu ini membahas hal ihwal yang terkait dengan Nabi khususnya dari segi dapat tidaknya dijadikan hujjah atau dalil agama Islam.

\footnotetext{
${ }^{1}$ Dosen Tetap IAI MUhammadiyah Sinjai
} 
Mengingat pentingnya hal tersebut di atas, maka mempelajari keberadaan masyarakat sekitar yang mempengaruhi lahirnya hadis merupakan sesuatu yang tidak dapat ditinggalkan. Di mana karena masyarakat di sekitar Nabi itulah yang akhirnya melahirkan hadis. Pada pembahasan dalam tulisan ini akan dibahas terkait dengan keberadaan masyarakat sekitar Nabi dan pengaruhnya terhadap lahirnya hadis, juga akan membahas cara penyampaian hadis serta beberapa sahabat yang terlibat langsung dengan lahirnya sebuah hadis.

\section{B. Rumusan Masalah}

Terkait dengan latar belakang di atas, maka pada tulisan ini dapat dirumuskan beberapa masalah yang berusaha penulis bahas, antara lain: 1) Bagaimana pengaruh masyarakat sekitar terhadap keberadaan hadis?; 2) Bagaimana cara penyampaian hadis dari Nabi kepada para sahabat?; dan 3) Bagaimaan peran sahabat dalam pembentukan hadis?

\section{PEMBAHASAN}

\section{A. Gambaran Kondisi Masyarakat Makkah dan Madinah pada Masa Awal}

\section{Islam}

1. Kondisi Masyarakat Makkah dan Hadis yang Terbentuk pada Masa itu

Menjelang kedatangan agama Islam, semua penduduk Makkah mengaku sebagai keturunan Quraisy atau Fihr atau an-Nadir. Namun demikian, mereka terbagi-bagi lagi dalam beberapa kabilah. Yang paling berpengaruh adalah Bani Hasyim, Bani Umayyah, Bani Naufal, Bani Zuhra, Bani Asad, Bani Ta’im, Bani Makhzum, Bani 'Adi, Bani Djamah, dan Bani Sahm.

Kota Makkah merupakan tempat tinggal suku-suku Quraisy, yang sewaktu-waktu pada musim panas pindah ke Syam (Suriah) dan pada musim dingin ke Yaman. Tetapi waktu itu sudah ada pengaturan tentang tugas-tugas yang menyangkut ibadah dan sosial kemasyarakatan. Pembagian tugas tersebut antara lain: Hijabah (memegang kunci pintu Ka'bah), Siqayah (mengawasi mata air zamzam), Rifadah (menyediakan makanan bagi para tamu), Nadwah (memimpin rapat antar suku), Liwa 
(mengatur panji-panji perang), dan Qiyadah (memimpin pasukan perang jika harus terjadi perang). ${ }^{2}$

Mengingat pentingnya sebuah suku dalam komunitas Makkah, maka Nabi diperintahkan untuk mula-mula menyebarkan Islam di kalangan kerabatnya -seperti besarnya pengaruh suku Quraisy di kalangan penduduk Makkah yang karenanya bisa dibayangkan betapa terpukulnya Muhammad SAW ketika ia mengumpulkan keluarganya dalam suatu jamuan santai dan mengajak mereka ke jalan Allah, namun ternyata keluarganya menolak dan hanya Ali bin Abi Thalib yang berani dan mau menjadi pembantunya. Puluhan orang yang hadir mentertawakan Muhammad dan Ali. Tidak seorangpun menyadari bahwa beberapa di antara para undangan ini akan ditebas oleh Ali di medan Badar, empat belas tahun kemudian, sebagai bukti kesungguhan Ali.

Besarnya pengaruh suku Quraisy di Makkah jugalah yang salah satunya bisa membuat Hamzah memeluk Islam, yakni ketika Abu Jahl dari bani Hanzhalah mencaci dan mengejek Muhammad, lalu orang-orang melapor pada Hamzah dan serta merta Hamzah-lah yang menghajar kepala Abu Jahl dengan busur panahnya. Insiden ini akan berbuntut panjang kalau saja spirit suku saat itu tidak segera padam.

Ketika Abu Thalib masih hidup, bani Hasyim memberikan perlindungan pada Muhammad dan tidak ada yang berani membunuh Muhammad karena Baninya akan membalas nantinya. Ketika Islam hadir di Makkah dapatlah kita baca dalam beberapa literatur bahwa pada fase Makkah bercirikan ajaran Tauhid. Tetapi sesungguhnya bukan hanya persoalan teologis semata, juga seruan Islam akan keadilan sosial, seperti perhatian pada nasib anak yatim, fakir miskin dan pembebasan budak serta ajaran Islam akan persamaan derajat manusia, yang menimbulkan penolakan keras penduduk Makkah pada Muhammad. Bagi mereka, agama ini tidak hanya "merusak" ideologi dan teologi mereka, tetapi juga "merombak" kehidupan sosial mereka.

${ }^{2}$ Dewan Redaksi Ensiklopedi Islam, Ensiklopedi Islam Jilid 3, (Jakarta: PT. Ichtiar Baru Van Hoeve, 2002), 220. 
Dapatlah diambil kesimpulan secara tentatif bahwa masyarakat Islam pada kurun Makkah belum lagi tercipta sebagai sebuah komunitas yang mandiri dan bebas dari urusan Bani. Negara Islam juga belum terbentuk pada dakwah Islam fase Makkah. Ajaran Islam pada fase Makkah bercirikan tauhid dan dalam titik tertentu terjadi radikalisasi makna dalam pandangan Arab jahiliyyah yang berimplikasi mengguncang tataran sosioreligius penduduk Makkah. Kita akan melihat bagaimana ciri umum ajaran Islam dan masyarakat Islam berkembang pada fase Madinah, untuk itu mari kita bahas dakwah Islam fase Madinah.

2. Kondisi Masyarakat Madinah dan Pembentukan Hadis.

Perkembangan Islam pada masa Madinah setelah Nabi SAW hijrah bisa dikatakan sebagai masa penyempurnaan Agama Islam. Hijrah ke Madinah tidaklah terwujud begitu saja (atau sekonyong-konyong). Ada beberapa pra-kondisi seperti Bai at Aqabah (pertama dan kedua). Kedua Ba iat ini merupakan batu-batu pertama bagi bangunan negara Islam. Kehadiran Rasulullah SAW melalui peristiwa hijrah ke dalam masyarakat Madinah yang majemuk amat menarik untuk dibahas. Peta demografis Madinah saat itu adalah sebagai berikut:

1. Kaum Muslimin yang terdiri dari Muhajirin dan Anshar

2. Anggota suku Aus dan Khazraj yang masih berada pada tingkat nominal muslim, bahkan ada yang secara rahasia memusuhi Nabi saw.

3. Anggota suku Aus dan Khazraj yang masih menganut paganism

4. Orang-orang Yahudi yang terbagi dalam tiga suku utama: Bani Qainuqa, Bani Nadhir dan Bani Quraidloh.

Kemajemukan komunitas tersebut tentu saja melahirkan konflik dan tension. Pertentangan suku Aus dan Khazraj sudah terlalu terkenal dalam sejarah Islam. Bahkan diduga diterimanya Rasul di Madinah (Yatsrib) dengan baik di kedua Bani tersebut karena kedua Bani tersebut membutuhkan "orang ketiga" dalam konflik diantara mereka. Hal ini bisa dipahami dalam manajemen konflik politik. Adapun diterimanya Rasul oleh kaum Yahudi merupakan catatan tersendiri. Tentu saja Yahudi menerima Nabi dengan penuh kecurigaan tetapi pendekatan yang 
dilakukan Nabi mampu merangkul mereka, paling tidak, sampai Nabi eksis di Madinah.

Kemajemukan komunitas Madinah membuat Rasul melakukan negosiasi dan konsolidasi melalui perjanjian tertulis yang terkenal dengan "Piagam Madinah". Piagam Madinah sesungguhnya merupakan rangkaian penting dari proses berdirinya negara Madinah, meskipun Nabi, selaku "mandataris" Piagam Madinah tidak pernah mengumumkan bahwa beliau mendirikan negara, dan tidak satupun ayat al-Qur'an yang memerintahkan beliau untuk membentuk suatu negara.

Dari sudut pandang ilmu politik, obyek yang dipimpin oleh Nabi saw.memenuhi syarat untuk disebut sebagai negara. Syarat berdirinya negara ialah ada wilayah, penduduk dan pemerintahan yang berdaulat. Kenyataan sejarah menunjukkan adanya elemen negara tersebut. Walhasil, setelah melalui proses Ba iat dan Piagam Madinah Nabi dipandang bukan saja sebagai pemimpin rohani tetapi juga sebagai kepala negara.

Kita beralih pada persoalan ajaran Islam. Pada fase Madinah ini ajaran Islam merupakan kelanjutan dari dakwah fase Makkah. Bila pada fase Makkah, ayat tentang hukum belum banyak diturunkan, maka pada fase Madinah kita mendapati ayat hukum mulai turun melengkapi ayat yang telah ada sebelumnya. Ini bisa dipahami mengingat hukum bisa dilaksanakan bila komunitas telah terbentuk. Juga dapat dicatat kemajemukan komunitas Madinah turut mempengaruhi ayat hukum ini. Satu contoh menarik pada peristiwa kewajiban zakat dan pelarangan riba. Setting sosio-ekonomi Madinah yang dikuasai oleh Yahudi memerlukan sebuah "perlawanan" dalam bentuk zakat (untuk pemerataan ekonomi di kalangan muslim) dan pelarangan riba. Yang terakhir ini membawa implikasi baik secara ekonomi maupun politik bagi praktek riba kaum Yahudi.

Bukan hanya ayat hukum saja yang berangsur-angsur "sempurna", juga ayat tentang etika, tauhid dan seluruh elemen ajaran Islam berangsurangsur mendekati titik kesempurnaan, dan mencapai puncaknya. Setelah Nabi wafat, dimulailah era Khulafa' al-Rasyidin. Tidak dapat dipungkiri, 
di Madinah Islam sempurna dan disinilah awal sebuah peradaban yang dibangun oleh umat Islam mulai tercipta.

Madinah merupakan Dar al-Hijrah, ibu kota negara Islam yang menampung Rasul SAW. sesudah hijrah disertai para sahabat. Ia menjadi saksi pembentukan syariat masa permulaan Islam. Di masjid-masjidnya, kaum muslimin mengitari Nabi SAW., menerima Al-Qur'an dan mendengarkan hadis. Di sanalah mereka menyaksikan keputusan Rasul SAW., pembagian harta rampasan yang beliau lakukan, pembakaran semangat para prajurit dan reaksi beliau terhadap para musuh. Ke sanalah kaum muslimin muhajirin mengungsi dengan membawa agama mereka, di bawah tekanan kaum Quraisy dan kabilah-kabilah di bagian tepi kawasan Arabia. Kepadanyalah seluruh pandangan bergantung dan seluruh angan menjadi bulat. Sampai ada Ahulh al-Hudaibiah, lalau al-Fath al-'Adlam (Fath Makkah). Kemudian ia menjadi pusat kegiatan politik dan ibu kota negara Islam sampai awal kekhalifahan Ali ra.

Di Madinah kita bias melihat sahabat-sahabat besar yang sangat mendalam ilmunya. Mereka juga memiliki peranan yang sangat besar dalam masalah hadis. Antara lain: Abu Bakar, Umar, Utsman, Ali, Abu Hurairah, 'Aisyah Umm al-Mukminin, Abdullah ibn Umar, Abu Sa'id alKhudriy, dan Zaid ibn Tsabit yang popular dengan pemahamannya yang mendalam terhadap Al-Qur'an, hadis dan khususnya fara'idh.

Di Madinah juga lulus beberapa tabi'in besar, yang antara lain: Sa'id ibn al-Musayyab, 'Urwah ibn az-Zubair, Ibn Syihab az-Zuhriy, Ubaidillah ibn 'Utbah ibn Mas'ud, Salim ibn Abdillah ibn Umar, Muhammad ibn al-Munkadir dan lain-lain yang menjadi rujukan umat dalam masalah sunnah, qadha', dan fatwa. ${ }^{3}$

\section{B. Peran Sahabat dalam Membentuk Hadis}

1. Hadis pada masa Rasul SAW.

Pada masa ini, Nabi SAW hidup di tengah-tengah masyarakat pada umumnya dan di tengah-tengah para sahabat pada khususnya, baik

\footnotetext{
${ }^{3}$ Muhammad 'Ajaj Al-Khathib, Ushul Al-Hadis (Pokok-Pokok Ilmu Hadis), (Jakarta: Gaya Media Pratama, 1998), 110.
} 
sewaktu beliau tinggal di Makkah maupun setelah hijrah ke Madinah. Seperti anggota masyarakat pada umumnya, Nabi SAW pun bergaul dan berbicara dengan orang lain dan para sahabatnya di rumah, di masjid, di pasar, di jalan, dan dalam keadaan musafir ataupun tidak. Para sahabatnya pun dengan bebas mengunjungi dan berbicara dengannya kapan dan di mana saja, kecuali pada waktu dan situasi tertentu seperti yang diajarkan al-Quran. Misalnya larangan menemui Nabi SAW pada saat sedang istirahat.

Kemudahan untuk melihat dan berjumpa dengan Nabi SAW membuat seluruh ucapan-ucapannya, tingkah laku serta perbuatannya, dan sikap-sikapnya dengan mudah pula menjadi tumpuan perhatian dan pengamatan para sahabat. Semua segi dari sosok Nabi SAW meraka jadikan sebagai teladan kehidupan. Pada sisi lain, Nabi SAW yang kalau berbicara perlahan, jelas, dan kalau perlu mengulangi ucapannya itu, memiliki kemampuan menggunakan dialek-dialek mitra bicaranya atau orang-orang yang dihadapinya. Ide-ide dan ucapannya seringkali dirasakan oleh mitra dialognya sebagai sesuatu yang sangat memukau. Di masa ini, Nabi SAW memerintahkan untuk menulis setiap wahyu yang turun. Di masa ini juga terdapat larangan menulis hadis. Tetapi dengan berbagai alas an, sebagian sahabat berinisiatif menulisnya di samping wahyu al-Quran. Larangan tersebut bukan karena dikuatirkan akan bercampur-baur dengan al-Quran, akan tetapi semata-mata supaya supaya semua potensi ditujukan dan diarahkan pada al-Quran. ${ }^{4}$

Di masa ini, dapat disebutkan beberapa cara sahabat dalam menerima hadis, antara lain:

a. Para sahabat memperoleh hadis dengan mengikuti majelis-majelis Nabi.

Seluruh majelis yang diasuh oleh Nabi merupakan majelis ilmu yang banyak memberikan manfaat bagi umat. Ia memberikan waktu khusus pengajaran kepada para sahabat, seperti pada saat khutbah Jum'at, memperingati hari raya, setelah salat berjamaah, dan waktu-

${ }^{4}$ Dewan Redaksi Ensiklopedi Islam, Ensiklopedi Islam jilid 3, 42-43 
waktu lain yang tidak ditentukan sesuai dengan kondisi yang dikehendaki.

Para sahabat juga sangat antusias menghadiri majelis-majelis yang diselenggarakan Nabi, di samping mereka juga melakukan usaha-usaha untuk memenuhi kebutuhan hidup mereka, seperti berdagang yang merupakan aktivitas dimana kebanyakan dilakukan oleh kalangan masyarakat Arab pada waktu itu. ${ }^{5}$

Di antara mereka ada yang secara sengaja membagi tugas untuk mendapatkan informasi yang berasal dari Nabi. 'Umar ibn al-Khathab misalnya, membagi tugas dengan tetangganya untuk mendapatkan hadis dari Nabi. Bila tetangganya pada suatu hari menemui Nabi, maka Umar esok harinya. Pihak yang bertugas menemui Nabi dan memperoleh berita yang berasal atau berkenaan dengan Nabi, maka dia segera menyampaikan berita itu kepada yang tidak bertugas. 'Umar ibn Khathab sewaktu-waktu bergantian dengan dengan Ibn Zayd, dari Bani Umayah untuk menghadiri majelis Nabi, ketika berhalangan hadir, berkata: "Kalau hari ini aku yang turun atau pergi, pada hari lainnya ia yang pergi, demikian pula aku yang melakukannya". 6 Dengan demikian, para sahabat Nabi yang kebetulan sibuk tidak sempat menemui Nabi, mereka tetap juga dapat memperoleh hadis dari sahabat yang sempat bertemu dengan Nabi. Pada saat yang demikian terjadi periwayatan hadis oleh sahabat dari sahabat lain. Pada masa Nabi, hadis tidak semata-semata diriwayatkan dari Nabi, tetapi sebagiannya diriwayatkan oleh sahabat dari sahabat yang lain.

Tidak jarang kepala-kepala suku yang jauh dari Madinah mengirim utusannya ke majelis Nabi, untuk kemudian mengajarkannya kepada suku mereka sekembalinya dari sana. Misalnya, yang dilakukan oleh Malik ibn al-Huwayris yang pernah

${ }^{5}$ Zainul Arifin, Studi Kitab Hadis, (Surabaya: Al-Muna, 2010), 16-17.

${ }^{6}$ Ibnu Hajar Al-Asqalani, Fath Al-Bari, Jilid I, (Beirut: Dar Al-Fikr wa Maktabah AlSalafiyah, t.t), 150 seperti dikutip oleh Munzier Suparta, Ilmu Hadis, (Jakarta: PT. Raja Grafindo Persada, 2003), 72. 
tinggal bersama Nabi selama dua puluh malam, sebagai salah satu anggota rombongan kaumnya. Ia menyatakan bahwa Nabi adalah seorang yang penyayang dan akrab. Katanya: "Tatkala Nabi melihat kami telah merasa rindu kepada para keluarga kami” beliau bersabda: "Kalian pulanglah, tinggallah bersama keluarga kalian, ajarilah mereka, dan lakukan shalat bersama mereka. Bila telah masuk waktu shalat, hendaklah salah seorang dari kalian melakukan azan, dan hendaklah yang tertua menjadi imam. Pengalaman Malik ibn Huwayris menunjukkan bahwa pada zaman Nabi, para sahabat sangat besar minatnya menimba pengetahuan langsung dari Nabi, termasuk hadis yang kemudian mereka ajarkan kepada keluarga mereka masing-masing. ${ }^{7}$

b. Dalam banyak kesempatan Rasulullah juga menyampaikan hadisnya melalui para sahabat tertentu, yang kemudian disampaikannya kepada orang lain. Hal ini karena terkadang ketika ia mewurudkan hadis, para sahabat yang hadir hanya beberapa orang saja, baik karena disengaja oleh Rasul SAW. sendiri atau secara kebetulan para sahabat yang hadir hanya beberapa orang saja, bahkan hanya satu orang, seperti hadis-hadis yang ditulis oleh Abdullah ibn Amr ibn Al-'Ash. ${ }^{8}$

c. Untuk hal-hal sensitif, seperti yang berkaitan dengan soal keluarga dan kebutuhan biologis, terutama yang menyangkut hubungan suami istri, Nabi menyampaikan melalui istri-istrinya. Seperti kasus hadis ketika Nabi menjelaskan tentang seorang wanita yang bertanya kepada Nabi SAW. tentang mandi bagi wanita yang telah suci dari haidnya. Pada hadis ini, Nabi dibantu oleh 'Aisyah, istrinya, untuk menjelaskan hal sensitive berkenaan dengan kewanitaan. ${ }^{9}$

d. Melalui ceramah atau pidato di tempat terbuka, seperti ketika haji wada' dan futuh Makkah. ${ }^{10}$

\footnotetext{
${ }^{7}$ Idri, , Studi Hadis, (Jakarta: Kencana Prenada Media Group, 2010), 32-34.

${ }^{8}$ Munzier Suparta, Ilmu Hadis. 73.

${ }^{9}$ Idri, Studi Hadis. 34

${ }^{10}$ Mushthafa Al-Siba'i, Al-Sunnah wa Makanaatuha fi Al-Tasyri' Al-Islami, (Kairo: Dar Al-Salam, 1998), Cet. Ke-1, hlm. 64 seperti dikutip oleh Drs. Munzier Suparta, MA,
} Ilmu Hadis, 73. 
e. Melalui perbuatan langsung yang disaksikan oleh para sahabatnya, yaitu dengan jalan musyahadah, seperti yang berkaitan dengan praktik-praktik ibadah dan muamalah. Peristiwa-peristiwa yang terjadi pada Nabi lalu Nabi menjelaskan hukumnya dan berita itu tersebar di kalangan umat Islam. ${ }^{11}$ Misalnya, suatu ketika Nabi berjalan-jalan di pasar dan bertemu dengan seorang laku-laki yang sedang membeli makanan (gandum). Nabi menyuruhnya memasukkan tangannya ke dalam gandum itu, dan ternyata di dalamnya basah, lalu Nabi bersabda: "Tidak termasuk golongan kami orang yang menipu". 12

Para sahabat menerima hadis (syariat) dari Rasul SAW adakala langsung dari beliau sendiri, yakni mereka langsung mendengar sendiri dari Nabi, baik karena ada sesuatu soal yang dimajukan oleh seseorang lalu Nabi menjawabnya, ataupun karena Nabi sendiri yang memulai pembicaraan, adakala tidak langsung yaitu mereka menerima dari sesama sahabat yang telah menerima dari Nabi, atau mereka menyuruh seseorang bertanya kepada Nabi, jika mereka sendiri malu untuk bertanya. ${ }^{13}$

Pada masa Nabi, sedikit sekali sahabat yang dapat menulis, sehingga yang menjadi andalan mereka dalam menerima hadis adalah ingatan mereka. ${ }^{14}$ Menurut 'Abd al-Nashr, Allah telah memberikan keistimewaan kepada para sahabat kekuatan daya ingat dan kemampuan menghafal. Mereka dapat meriwayatkan al-Quran, hadis, syair, dan lain lain dengan baik. Seakan mereka membaca dari sebuah buku. $^{15}$

${ }^{11}$ Muhammad 'Ajjaj al-Khathib, al-Sunnah qabl al-Tadwin, (Beirut: Dar al-Fikr, 1971), hlm. 15-16, seperti dikutip oleh Idri, Studi Hadis, 35

${ }^{12}$ Ahmad Ibn Hanbal, Musnad Ahmad, (Beirut: Dar al-Fikr, tth), juz 13, hlm. 18 seperti dikutip oleh Dr. Idri,M.Ag., Studi Hadis, 35.

${ }^{13}$ Tengku Muhammad Hasbi Ash-Shiddieqy, Sejarah \& Pengantar Ilmu Hadits, (Semarang: PT. Pustaka Rizki Putra, 1999), 31.

${ }^{14}$ Muhammad Muhammad Abu Zahw, al-Hadits wa al-Muhadditsun, (Mesir: Syirkah Sahimah Mishriyah, 1987), hlm. 48 seperti dikutip oleh Idri, Studi Hadis, 35.

${ }^{15}$ Abd al-Nashr Tawfiq al-'Aththar, Dustur al-Lammah wa 'Ulum al-Sunnah, (Kairo: Maktabah Wahhab, tth), hlm. 71 seperti dikutip oleh Dr. Idri, M.Ag., Studi Hadis, 35-36. 
Hadis pada masa Nabi pada umumnya hanya diingat dan dihapal oleh mereka tidak ditulis seperti Al-Quran ketika disampaikan Nabi, karena situasi dan kondisi yang tidak memungkinkan. Dr. Mushthafa As-Siba’i menyampaikan beberapa alasan di antaranya:

a. Al-Qur'an masih turun kepada Nabi Muhammad SAW dan kondisi penulisannya masih sangat sederhana ditulis di atas pelepah kurma, kulit, tulang binatang, dan batu-batuan dan belum dibukukan.

b. Kemampuan tulis menulis bagi para sahabat pada awal Islam masih sangat langka dapat dihitung dengan jari dan mereka sudah difungsikan sebagai penulis wahyu Al-Qur'an.

c. Ingatan orang-orang Arab yang dikenal bersifat ummi (tidak bisa baca tulis) sangat kuat dan diandalkan Rasu untuk mengingat hadis. ${ }^{16}$

Rasulullah tidak pernah memerintah sahabat tertentu untuk menulis hadis dan membukukannya sebagaimana al-Qur'an yang ditulis secara resmi oleh Zayd ibn Tsabit, sekretaris pribadi beliau. Bahkan, dalam suatu kesempatan Nabi pernah melarang menulis hadis sebagaimana diriwayatkan oleh Abu Sa'id al-Khudzri bahwa Nabi bersabda: “Janganlah kalian tulis dariku (selain al-Qur'an) dan barangsiapa yang menulis dariku selain al-Qur'an, maka hapuslah. Riwayatkan hadis dariku tidak apa-apa. Barangsiapa berdusta atas namaku - Himam berkata, aku menyangka beliau bersabda - maka hendaklah ia menempati tempat duduknya di neraka." 17

Larangan ini dilakukan karena khawatir hadis bercampur dengan alQur'an yang saat itu masih dalam proses penurunan. Dalam kesempatan lain, sebagaimana diriwayatkan oleh 'Abd Allah ibn 'Umar katanya: “Aku pernah menulis segala sesuatu yang kudengar dari Rasulullah, aku ingin menjaga dan menghafalkannya. Tetapi orang-orang Quraisy melarangku melakukannya. Mereka bekata: "Kamu hendak menulis (hadis) padahal Rasulullah bersabda dalam keadaan marah dan senang”. Kemudian aku

${ }^{16}$ Mushthafa Al-Siba'i, Al-Sunnah wa Makanaatuha fi Al-Tasyri' Al-Islami, hlm. 6667 seperti dikutip oleh Dr. H. Abdul Majid Khon, M.Ag., Ulumul Hadis, (Jakarta: Amzah, 2009), Cet. Ke-3, hlm. 44.

${ }^{17}$ Al-Nawawi, Shahih Muslim bi Syarh al-Nawawi, (Indonesia: Maktabah Dahlan, tth), hlm. 2298, seperti dikutip oleh Dr. Idri, M.Ag., Studi Hadis, 36. 
menahan diri (untuk tidak menulis hadis) hingga aku ceritakan hal itu kepada Rasulullah. Beliau bersabda: "Tulislah, maka demi Dzat yang aku berada dalam kekuasaan-Nya tidaklah keluar dariku seain kebenaran". ${ }^{18}$

Semua penulis sejarah Nabi, ulama' hadis dan umat Islam sepakat bahwa al-Qur'an memperoleh perhatian yang penuh dari Rasulullah maupun dari sahabat. Nabi selalu memerintahkan kepada sahabat untuk menghafal dan menulisnya di lampiran-lampiran, tulang, pelepah korma, batu dan lain-lain.

Ini sangat berbeda dengan hadis, walaupun ia merupakan sumber yang penting dari sumber tashri', tetapi tidak mendapatkan perhatian yang sedemikian. Hadis tidak ditulis bahkan Rasulullah tidak pernah memerintah sahabat untuk menghafalnya. Hal tersebut diperkuat dengan pendapatnya Ibnu Hajar yang menyebutkan bahwa hadis Nabi belum disusun dan dibukukan pada masa sahabat dan tabi' in senior. ${ }^{19}$

Dalam mencari solusi dua versi hadis yang kontra di atas para ulama berbedap pendapat. Di antara mereka berpendapat bahwa hadis yang melarang penulisan dihapus (di-nasakh) dengan hadis yang memperbolehkannya. ${ }^{20}$ Ulama lebih cenderung kompromi antar dua hadis yang kontra itu dengan melakukan takhshish al-amm. ${ }^{21}$ Maksud larangan dlam hadis bagi orang yang kuat hafalannya, sedangkan kebolehannya bagi orang yang kurang kuat hafalannya. Atau larangan bagi orang yang kurang ahli dalam menulis dikhawatirkan campur tulisannya dengan al-Qur'an misalnya ditulis dalam satu lembar.

Ajaj Al-Khathib - seorang Ketua Jurusan dan Guru Besar Hadis dan ilmunya di Universitas Damaskus - mengemukakan bahwa setelah alQur'an terkodifikasi pada masa Abu Bakar dan terlebih pada masa Utsman yang kemudian dikirim ke berbagai penjuru mereka mempelajari sunnah,

\footnotetext{
${ }^{18}$ Ahmad Ibn Hanbal, Musnad Ahmad, hlm. 49, seperti dikutip oleh Dr. Idri, M.Ag., Studi Hadis, 36

${ }^{19}$ Prof. Dr. H. Zainul Arifin, MA, Studi Kitab Hadis, (Surabaya: Al-Muna, 2010), Cet. Ke-2, hlm.23

${ }^{20}$ Dr. H. Abdul Majid Khon, M.Ag., Ulumul Hadis, hlm. 45.

${ }^{21}$ Ibnu Qutaibah Ad-Dainuri, Ta'wil Mukhtalif Al-Hadits, hlm. 260 dan Mahmud Yunus, 'Ilmu Mushthalah Al-Hadits, hlm. 6, seperti dikutip oleh Dr. H. Abdul Majid Khon, M.Ag., Ulumul Hadis, hlm. 46.
} 
bermudzakarah, dan menulisnya, bahkan mereka menganjurkan dan memperbolehkan pengkodifikasiannya. Demikian juga para sahabat lain yang semula melarang menulis sunnah akhirnya memperbolehkannya bahkan menganjurkannya setelah tidak ada kekhawatiran pemeliharaan AlQur'an seperti Abdullah bin Mas'ud, Ali bin Abi Thalib, Hasan bin Ali, Mu'awiyah, Abdullah bin Abbas, Abdullah bin Umar, Anas bin Malik, dan lain-lain. $^{22}$

2. Perkembangan Hadis pada Masa Sahabat

Setelah Nabi wafat, para sahabat tidak dapat mendengar sabdasabda, menyaksikan perbuatan-perbuatan, dan hal ihwal Nabi secara langsung. Tindak tanduk Nabi, yang pada dasarnya bermuatan ajaran Ilahi, hanya dapat diketahui melalui informasi para sahabat Nabi, sebagai periwayat pertama yang menyampaikan hadis kepada umat muslim. Periwayatan hadis semenjak itu mengalami perkembangan dan melibatkan banyak pihak. Para sahabat tidak ada yang mendustakan Nabi. Mereka orang-orang yang rela mengorbankan jiwa dan raga demi menegakkan agama dan membantu dakwah Islam. ${ }^{23}$

Ada beberapa orang sahabat yang tercatat sebagai sahabat yang banyak menerima hadis dari Rasul SAW. dengan beberapa penyebabnya. Mereka itu antara lain:

a. Para sahabat yang tegolong kelompok Al-Sabiqun Al-Awwalun (yang mula-mula masuk Islam), seperti Abu Bakar, Umar ibn Khattab, Utsman bin Affan, Ali ibn Abi Thalib dan Ibn Mas'ud. Mereka banyak menerima hadis dari Rasul SAW. karena lebih awal masuk Islam dari sahabat-sahabat lainnya.

b. Ummahat Al-mukminin (istri-istri Rasul SAW.), seperti Siti Aisyah dan Ummu Salamah. Mereka secara pribadi lebih dekat dengan Rasul SAW daripada sahabat-sahabat lainnya. Hadis-hadis yang

${ }^{22}$ Muhammad 'Ajaj Al-Khathib, As-Sunnah Qabl At-Tadwin, (Beirut: Dar Al-Fikr, 1997), Cet. Ke-7, hlm. 208-211, seperti dikutip oleh Dr. H. Abdul Majid Khon, M.Ag., Ulumul Hadis, hlm. 48.

${ }^{23}$ Shalah al-Din ibn Ahmad al-Adhabi, Manhaj Naqd al-Matn 'Ind 'Ulama' al-Hadits al-Nabawi, (Beirut: Dar al-Aflaq al-Jadidah, 1983 M), hlm. 47 seperti dikutip oleh Dr. Idri, M.Ag., Studi Hadis, hlm. 39. 
diterimanya, banyak yang berkaitan dengan soal-soal keluarga dan pergaulan suami istri.

c. Para sahabat yang di samping selalu dekat dengan Rasul SAW., akan tetapi juga banyak menuliskan hadis-hadis yang diterimanya, seperti Abdullah Amr ibn Al-'Ash.

d. Sahabat yang meskipun tidak lama bersama Rasul SAW., akan tetapi banyak bertanya kepada para sahabat lainnya secara sungguhsungguh, seperti Abu Hurairah.

e. Para sahabat yang secara sungguh-sungguh mengikuti majlis Rasul SAW. banyak bertanya kepada sahabat lain dari sudut usia tergolong yang hidup lebih lama dari wafatnya Rasul SAW., seperti Abdullah ibn Umar, Anas ibn Malik dan Abdullah ibn Abbas. ${ }^{24}$

Para sahabat dalam menerima hadis dari Nabi, berpegang kepada kekuatan hafalannya, yakni menerimanya dengan jalan hafalan bukan dengan jalan menulis. Sahabat-sahabat Rasul yang dapat menulis sedikit sekali. Mereka mendengar dengan hati-hati apa yang Nabi sabdakan. Lalu tergambarlah lafal atau makna itu dalam dzihin mereka. Mereka melihat apa yang Nabi kerjakan. Dan mereka mendengar pula dari orang yang mendengarnya sendiri dari Rasul. Karena tidaklah semua mereka pada setiap waktu dapat menghadiri majlis Nabi. Para sahabat menghafal hadis dan menyampaikannya kepada orang lain secara hafalan pula. Hanya beberapa orang sahabat saja yang mencatat hadis yang didengarnya dari Nabi. $^{25}$

Periwayatan hadis pada masa sahabat terutama masa al-Khulafa alRasyidun sejak tahun $11 \mathrm{H}$ sampai $40 \mathrm{H}$, yang disebut juga masa sahabat besar, belum begitu berkembang. perhatian para sahabat masih terfokus pada pemeliharaan dan penyebaran al-Qur'an dan mereka berusaha membatasi periwayatan hadis tersebut. Masa ini disebut dengan masa pembatasan dan memperketat periwayatan.

\footnotetext{
24 'Ajjaj al-Khatib, Ushul Al-Hadits 'Ulumuhu wa Mustalahuhu, (Beirut: Dar Al-Fikr, 1981), Cet. Ke-4, hlm. 71-72, seperti dikutip oleh Drs. Munzier Suparta, MA, Ilmu Hadis, 74.

${ }^{25}$ Tengku Muhammad Hasbi Ash-Shiddieqy, Sejarah \& Pengantar Ilmu Hadits, 31.
} 
Kehati-hatian para sahabat tidak berarti bahwa mereka selamanya mensyarakatkan bahwa hadis dapat diterima bila diriwayatkan oleh dua orang atau lebih atau periwayatan hadis harus disertai dengan saksi bahkan sumpah, tetapi maksudnya adalah mereka berhati-hati dalam menerima dan meriwayatkan hadis. ${ }^{26}$

Dengan demikian, para sahabat Nabi sangat kritis dan hati-hati dalam periwayatan hadis. Tradisi kritis di kalangan sahabat menunjukkan bahwa mereka sangat peduli tentang kebenaran dalam periwayatan hadis karena itu mereka:

a. Bersikap cermat dan hati-hati dalam menerima suatu riwayat.

b. Melakukan penelitian dengan cermat terhadap periwayat maupun isi riwayat itu sendiri.

c. Mengharuskan adanya saksi dalam periwayatan hadis.

d. Meminta sumpah dari periwayat hadis.

e. Menerima riwayat dari satu orang yang terpercaya.

f. Menerima periwayatan tanpa pengecekan terlebih dahulu apakah benar dari Nabi atau perkataan orang lain dikarenakan mereka memiliki agama yang kuat sehingga tidka mungkin berdusta. ${ }^{27}$

Para sahabat memang berbeda dalam banyak sedikitnya periwayatan, karena profesi mereka yang berbeda. Ada enam orang di antara sahabat yang tergolong banyak meriwayatkan hadis ialah:

1. Abu Hurairah sebanyak 5.374 buah hadis.

2. Abdullah bin Umar bin Al-Khathab sebanyak 2.635 buah hadis.

3. Anas bin Malik sebanyak 2.286 buah hadis.

4. Aisyah Ummi Al-Mukminin sebanyak 2.210 buah hadis.

5. Abdullah bin Abbas sebanyak 1.660 buah hadis.

6. Jabir bin Abdullah sebanyak 1.540 buah hadis. ${ }^{28}$

${ }^{26}$ Muhammad 'Ajjaj al-Khathib, Ushul al-Hadits, hlm, 91, seperti dikutip oleh Dr. Idri, M.Ag., Studi Hadis, hlm. 41.

${ }^{27}$ Muhammad 'Ajjaj al-Khathib, Ushul al-Hadits, hlm, 48-51, seperti dikutip oleh Dr. Idri, M.Ag., Studi Hadis, hlm. 41-42.

${ }^{28}$ Mahmud Ath-Thahan, Taysir Mushthalah Al-Hadits, (Beirut: Dar Ats-Tsaqafah AlIslamiyah, tth), hlm. 199, seperti dikutip oleh Dr. H. Abdul Majid Khon, M.Ag., Ulumul Hadis, hlm. 49. 
Sedangkan di antara sahabat yang sedikit dalam meriwayatkan hadis adalah Zubair bin Al-Awwam sekitar 38 buah hadis, Zaid bin Arqam sekitar 70 buah hadis, dan Imran bin Husan 180 buah hadis. $^{29}$

Sebagaimana para sahabat besar, para sahabat kecil dan tabi'in juga cukup berhati-hati dalam periwayatan hadis. Cara-cara yang ditempuh di samping yang dilakukan oleh para sahabat besar juga berbagai cara yang sesuai dengan hati nurani mereka dalam rangka untuk menyampaikan hadis pada generasi berikutnya secara benar dan tidak keliru.

Pada masa ini daerah kekuasaan Islam semakin luas. Banyak sahabat atau tabi'in yang pindah dari Madinah ke daerah-daerah yang baru dikuasai, di samping banyak pula yang masih tinggal di Madinah dan Makkah. Hadis-hadis yang diterima oleh para tabi'in ini ada dalam bentuk catatan-catatan atau tulisan-tulisan dan ada pula yang harus dihafal, di samping dalam bentuk-bentuk yang sudah terpolakan dalam ibadah dan amaliah para sahabat yang mereka saksikan dan mereka ikuti. Kedua bentuk ini saling melengkapi, sehingga tidak ada satu hadis pun yang tercecer atau terlupakan. Sungguhpun demikian, pada masa pasca sahabat besar ini muncul kekeliruan periwayatan hadis ketika kecermatan dan sikap hati-hati melemah.

Faktor-faktor penyebab terjadinya kekeliruan pada masa setelah sahabat itu antara lain: Pertama, periwayat hadis sebagaimana manusia lain tidak pernah terlepas dari unsur kekeliruan. Kedua, terbatasnya penulisan dan kodifikasi hadis. Ketiga, terjadinya periwayatan secara makna yang dilakukan oleh sebagian besar sahabat dan tabi'in terbukti adanya hadis atau kisah yang sama tetapi memiliki redaksi yang beragam. $^{30}$

${ }^{29}$ Abdul Majid Khon, Ulumul Hadis, hlm. 50.

${ }^{30}$ Muhammad 'Ajjaj al-Khathib, Ushul al-Hadits, hlm, 92, seperti dikutip oleh Dr. Idri, M.Ag., Studi Hadis, hlm. 44. 


\section{KESIMPULAN}

Hadis ( Sunnah) yang lahir tidak dapat terlepas dari kondisi dan situasi masyarakat dimana hadis itu terbentuk, serta tidak lepas dari peran sahabat pada masa itu. Masyarakat dan sahabat adalah merupakan subjek sekaligus objek dari terbentuknya hadis.

Hadis hadir mengiringi dan menjelaskan ayat-ayat Al-Qur'an, sekaligus sebagai jawaban-jawaban kejadian-kejadian atau kasus yang sedang terjadi baik masalah ibadah maupun muamalah. Mengingat pentingnya kedua faktor pembentuk lahirnya hadis, yaitu kondisi masyarakat dan peran sahabat, maka untuk mempelajari hadis pada saat ini tidak bisa mempelajari hadis berdasarkan teksnya belaka (tekstual), tetapi perlu juga mempelajari konteks saat hadis itu lahir. Berdasarkan uraian pembahasan di atas, jelaslah bahwa mempelajari hadis perlu mengkaji historis, sosiologis dan antropologis (kontekstual) masyarakat pada saat dimana hadis itu lahir. 


\section{DAFTAR PUSTAKA}

Arifin, Zainul, Studi Kitab Hadis, Surabaya: Al-Muna, 2010

Ash-Shiddieqy, Tengku Muhammad Hasbi, Sejarah \& Pengantar Ilmu Hadis, Semarang: PT. Pustaka Rizki Putra, 1999.

Baqi, Muhammad Fuad Abdul, Mutiara Hadis Shahih Bukhori Muslim, Surabaya: PT. Bina Ilmu, 2005

Dewan Redaksi Ensiklopedi Islam, Ensiklopedi Islam Jilid 3, Jakarta: PT. Ichtiar Baru Van Hoeve, 2002.

Idri, Studi Hadis, Jakarta: Kencana Prenada Media Group, 2010.

al-Khathib, Muhammad 'Ajaj, Ushul al-Hadis (Pokok-Pokok Ilmu Hadis), Jakarta: Gaya Media Pratama, 1998

Khon, Abdul Majid, Ulumul Hadis. Jakarta: Amzah, 2009.

Suparta, Munzier, Ilmu Hadis, Jakarta: PT. Raja Grafindo Persada, 2003. 